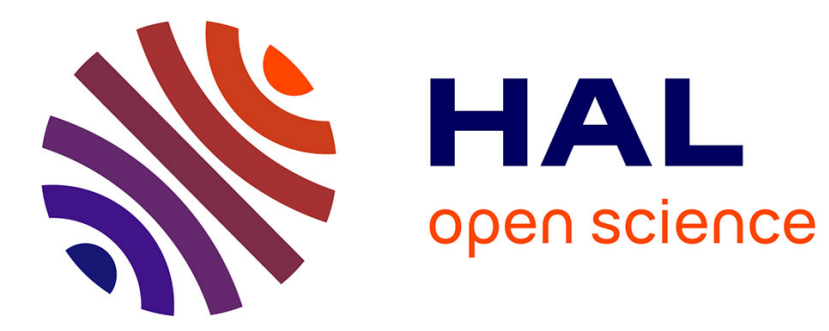

\title{
Characterization of internal erosion in sand kaolin soils
} Fateh Bendahmane, Didier Marot, Frédéric Rosquoët, Alain Alexis

\section{To cite this version:}

Fateh Bendahmane, Didier Marot, Frédéric Rosquoët, Alain Alexis. Characterization of internal erosion in sand kaolin soils. European Journal of Environmental and Civil Engineering, 2006, 10 (4), pp.505-520. 10.1080/17747120.2006.9692841 . hal-01005848

\section{HAL Id: hal-01005848 \\ https://hal.science/hal-01005848}

Submitted on 24 Feb 2017

HAL is a multi-disciplinary open access archive for the deposit and dissemination of scientific research documents, whether they are published or not. The documents may come from teaching and research institutions in France or abroad, or from public or private research centers.
L'archive ouverte pluridisciplinaire HAL, est destinée au dépôt et à la diffusion de documents scientifiques de niveau recherche, publiés ou non, émanant des établissements d'enseignement et de recherche français ou étrangers, des laboratoires publics ou privés. 


\title{
Characterization of internal erosion in sand kaolin soils
}

\section{Experimental study}

\section{Fateh Bendahmane - Didier Marot - Frédéric Rosquoët Alain Alexis}

Institut de recherche en génie civil et mécanique

GeM, UMR CNRS 6183

IUT de Saint-Nazaire

BP 420

F-44606 Saint-Nazaire cedex

fateh.bendahmane@univ-nantes.fr

\begin{abstract}
The appearance of breaches in recent hydraulic earthstructures due to internal erosion confirms that improving our physical understanding of the phenomenon is urgent. Under the effect of internal flows, earthstructures can undergo a migration of their particles, which modifies the particle size distribution and affects both hydraulic and mechanical characteristics. This paper initially presents a parametric study conducted on sand/kaolin samples. The experimental device described here consists of three modified triaxial cells used to control sample confinement, prevent any parasitic flow and survey sample large deformations. The tests reveal that internal erosion (suffusion or piping) is initiated by the transport of clay particles. The erosion rate, then, depends on the values of the different parameters considered (hydraulic gradient, clay content and filter pore opening size).
\end{abstract}

RESUMÉ. La rupture par érosion interne de récents ouvrages hydrauliques en terre souligne la nécessité d'améliorer la compréhension physique de ce phénomène. Les écoulements internes peuvent engendrer une migration de particules constitutives des ouvrages hydrauliques en terre. Cette migration affecte la distribution granulométrique, modifie la porosité ainsi que les caractéristiques mécaniques et hydrauliques. Nous proposons une étude expérimentale réalisée sur des échantillons constitués de mélanges de sable et de kaolin. Le montage expérimental est constitué de trois cellules triaxiales modifiées qui permettent de contrôler le confinement des échantillons, d'éviter tout écoulement parasite et de suivre les grandes déformations des échantillons. Les essais réalisés indiquent que l'érosion interne (suffusion ou renard) est initiée par la migration des particules d'argile. Le taux d'érosion dépend du gradient hydraulique appliqué, du pourcentage d'argile et de l'ouverture des pores du filtre.

KEYWORD: internal erosion, suffusion, piping, experimental study, cohesive soils.

MOTS-CLÉS: érosion interne, suffusion, renard, étude expérimentale, sols cohésifs. 


\section{Introduction}

Irreversible damages due to sliding, overtopping and internal erosion are caused by the presence of water within earthstructures. Among the 11192 embankment dams surveyed by Foster et al. (2000), 136 reveal some dysfunctions, which are divided up as $5.5 \%$ for sliding, $46 \%$ for internal erosion and $48 \%$ for overtopping. This statistic study proves that internal erosion is an important cause of failure. Internal erosion is due to the stripping and transport, under the action of flow, of some particles constituting the earthstructure. Structure hydraulic and mechanical properties are then modified. The material permeability, for instance, undergoes some sharp changes, which cause losses of tightness or interstitial over pressures. Internal erosion mechanisms are complex and involve many parameters, coupled or not. Previous laboratory test campaigns (Monnet, 1998; Skempton and Brogan, 1994) identify the mechanisms responsible for the migration of the particles as either suffusion or piping, depending on the interpretation. Suffusion is characterized by an internal redistribution of the fine particles within the soil and by the decrease of the permeability. Piping, on the other hand, is induced by a regressive erosion of particles from the soil downstream and along the upstream line towards an outside environment until forming a continuous pipe. The grain size distribution then varies according to the permeability increase. Piping initiation is difficult to detect, contrary to suffusion, and evolves very quickly.

Many parameters (porosity, grain size, confining pressure, hydraulic gradient) influence internal erosion behavior. Different criteria to assess the initiation and development of internal erosion are proposed in the literature (Kenney and Lau, 1985; Khilar et al., 1985). They mostly rest on the material particle size analysis or on the estimation of the erosion critical hydraulic gradient.

On the assumption that bigger grains can hinder the erosion of smaller grains, a method based on the shape of the coarse or the fine low-content grading curve has been developed (Kenney and Lau, 1985) and has been validated for both up and down flows (Monnet, 1998; Skempton and Brogan, 1994). Porosity and soil confinement, however, are not considered in the granulometric approach.

To characterize internal erosion initiation, many authors have developed some expressions of the critical hydraulic gradient. Some of these expressions are strongly dependent on the specific configuration studied and, therefore, cannot be applied generally. Regarding cohesive soils (Khilar et al., 1985), the erosion critical gradient is expressed as a function of the hydraulic shear stress $\tau$ (shear stress generated by flows within the soil porous system), of the intrinsic permeability $\mathrm{K}$ and of the porosity $\mathrm{n}$. The main difficulty, when using this model, lies in the determination of $\tau$, dependent upon both clay mineralogy and interstitial fluid properties (Arulanandan and Perry, 1983). For example, to characterize internal erosion initiation, Reddi et al. (2000) propose to model the soil using a cylindrical pipeline network and develop an expression of the shear stress $\tau$ for cohesive soils: 


$$
\tau=1.414\left(\frac{\Delta \mathrm{P}}{\Delta \mathrm{L}}\right) \sqrt{\frac{\mathrm{K}}{\mathrm{n}}}
$$

with $\Delta \mathrm{P} / \Delta \mathrm{L}$, the pressure gradient $\left(\mathrm{kN} / \mathrm{m}^{3}\right) ; \mathrm{K}$, the intrinsic permeability $\left(\mathrm{m}^{2}\right)$ and $\mathrm{n}$, the porosity.

The many parameters affecting the different phenomena, as well as their evolutive features emphasize the importance of taking suiting experimental precautions.

The present paper reports a study conducted at the Institut de Recherche en Génie Civil et Mécanique (GeM, Saint-Nazaire, France) to provide new data on the effects of internal erosion on sand/clay samples.

\section{Experimental device}

\subsection{Device description}

Internal erosion tests are realized using a new experimental device (Figure 1). It consists of three modified triaxial cells coupled with two pressure/volume controllers (GDS), placed in a temperature-controlled room $\left(20 \pm 1^{\circ} \mathrm{C}\right)$.

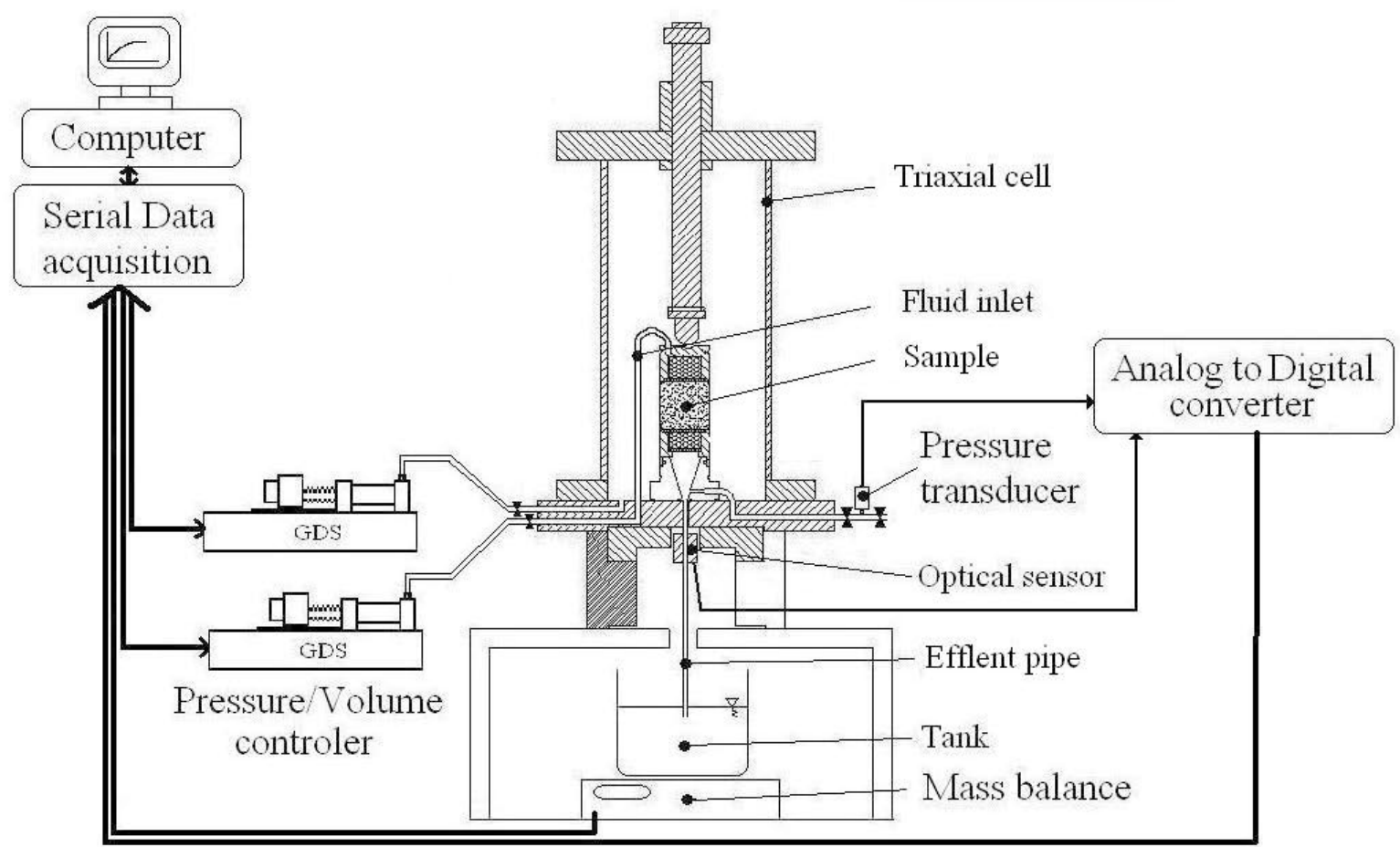

Figure 1. Schematic representation of the experimental triaxial cell equipped with the two GDS controllers, effluent weight measurement and optical sensor mechanism 
The triaxial cells have been modified in order to:

- let the flow come through the samples while limiting head losses;

- prevent the eroded particles from clogging the draining system.

The injection head consists of a glass sphere (diameter: $5 \mathrm{~mm}$ ) layer with a thickness of $22 \mathrm{~mm}$ to diffuse the fluid on the sample uniformly. At the bottom of the sample, the funnel-shaped draining system is specially designed to avoid clogging or the formation of a layer of particles within the system. This draining system makes it possible to use different filters, which can be either rigid or made of geotextiles with openings ranging between $0.001 \mathrm{~mm}$ and $8 \mathrm{~mm}$ and a maximum thickness of $17 \mathrm{~mm}$ (Figure 2).

A GDS (Geotechnical Digital System) is used to inject up to $200 \mathrm{~cm}^{3}$ of statically or dynamically pressurized fluid (maximum pressure: $600 \mathrm{kPa}$ ) with an accuracy of $0.001 \mathrm{~cm}^{3}$ and a resolution of $1 \mathrm{kPa}$.

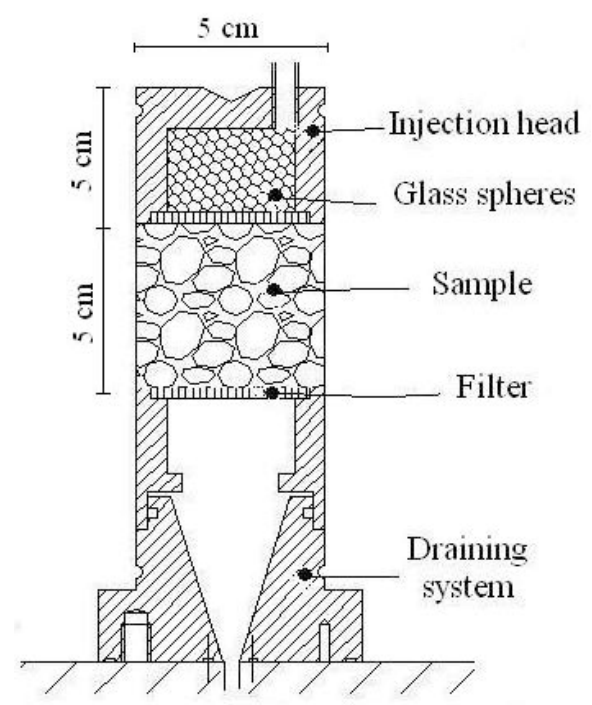

Figure 2. Details of the test piece with its injection head and the draining system

In order to detect the internal erosion initiation time and carry out real-time measurements of the eroded grain quantity, an optical sensor has been developed (Figure 3).

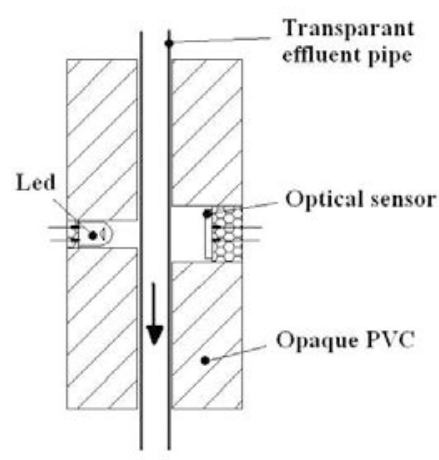

Figure 3. Details of the optical sensor placed on the transparent effluent pipe 
Placed on the transparent pipe connecting the triaxial cell to the effluent tank, it measures the transparency of the fluid coming through the pipe. A preliminary calibration on the suspensions of kaolin makes it possible to establish a relationship between transparency and concentration.

The mass of the outlet effluents, under a constant hydraulic gradient, is obtained using a weighing machine (accuracy: $0.1 \mathrm{~g}$ ). A computer operates the acquisition of data automatically every three seconds. The mass of the eroded material is obtained by computing the difference between the mass of inlet water and the mass of outlet effluent.

\subsection{Sample making}

The cohesive soil samples are recreated using a mechanical mixture of Loire sand and two types of clay (kaolin for the parametric study and bentonite for the validation test). Two different test samples are produced, some with a $10 \%$ kaolin content and others wit a 30\% kaolin content (in weight). The kaolin is marketed by Prolabo and its sedimentation analysis indicates that $10 \%$ of the clay particles are $<0.8 \mu \mathrm{m}$ and that the remaining $90 \%$ is $>8 \mu \mathrm{m}$. The Loire sand grain size distribution ranges between $80 \mu \mathrm{m}$ and $2 \mathrm{~mm}$ (Figure 4 ).

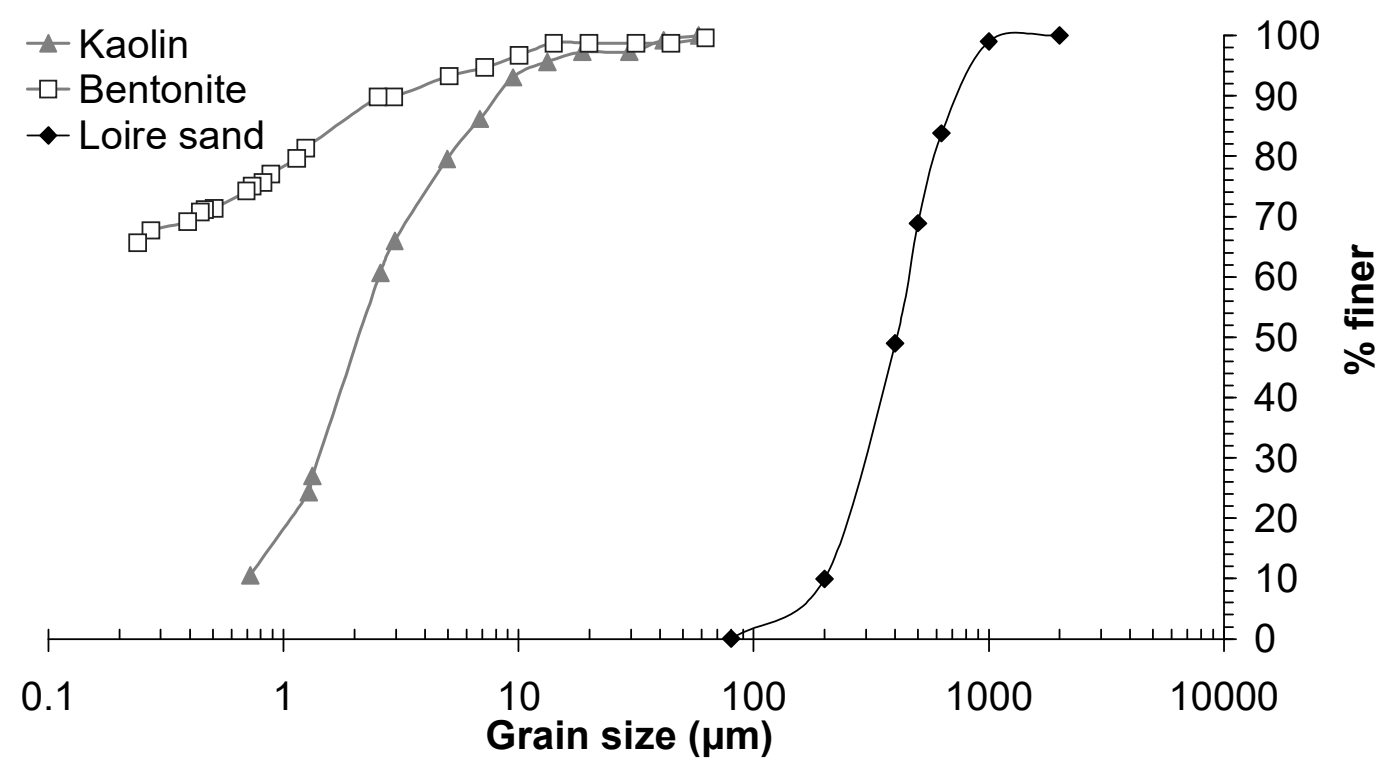

Figure 4. Grain size distributions for the Loire sand, the kaolin used for the erosion test, and the bentonite used for the permeability measurements

The repeatability of the production is guaranteed by the following procedure:

- First, the sand is mixed (145rpm) during three minutes with a water content of $8 \%$. While mixing continues, powder clay is progressively added and mixing is then carried on for some additional 10 minutes. This method has been validated through confirmation of the size distribution homogeneity achieved after mixing. The 
installation of the sample inside the cell requires preliminary forming using a $50 \mathrm{~mm}$ diameter and $50 \mathrm{~mm}$ high mould under the action of two pistons until the required dry density is reached (Bendahmane, 2002).

- Second, the sample is saturated with distilled water after application of a light confinement pressure to prevent any parasitic flow between the sample and the membrane. The saturation rate is reached sufficiently slowly (saturation time of 24 hours) to prevent small particles from migrating.

- Third, the cohesive sample is consolidated at $200 \mathrm{kPa}$ during 24 hours. The pressure of confinement increases in stages in conformity with Standard Afnor NFP 94-074. Excess pore pressure measurements are used to control the good quality of the sample consolidation. The confinement pressure is then decreased by half to avoid the material further consolidation because of the inflow.

\subsection{Validation tests (permeability measurements)}

The new experimental device is validated by carrying out permeability measurements on a sand-bentonite reconstituted material according to the experiment conditions defined by Kenney et al. (1992). The bentonite is a Prolabo (ref. 21791367) of montmorillonite type, whose sedimentation analysis shows that $65 \%$ of the particles are smaller than $0.2 \mu \mathrm{m}$ and none are bigger than $80 \mu \mathrm{m}$ (Figure 4). The chemical composition is $\mathrm{Al}_{2} \mathrm{O}_{3}: 15 \%, \mathrm{CaO}: 2 \%, \mathrm{Fe}_{2} \mathrm{O}_{3}: 1 \%, \mathrm{MgO}$ : $4 \%, \mathrm{SiO}_{2}: 60 \%$, alkalis and other: $3 \%$, Loss on ignition : $15 \%$.

According to their experimental conditions, which consists in an $8 \%$ sand/bentonite weight ratio, a $70 \mathrm{kPa}$ axial consolidation in a rigid cell permeameter (the cylindrical test pieces are $50 \mathrm{~mm}^{2}$ for the section and 25 to $30 \mathrm{~mm}$ for the height) and a $15-\mathrm{m} / \mathrm{m}$ hydraulic gradient, the hydraulic permeability $(\mathrm{k})$ measured by Kenney et al. (1992) ranges between $2 \cdot 1 \cdot 10^{-10}$ and $2 \cdot 2 \cdot 10^{-10} \mathrm{~m} / \mathrm{s}$. The samples used for the validation here have been reconstituted in the same sand/bentonite proportions and with an identical sand size distribution. The permeability measured on three different samples with the new device is $2.310^{-10} \mathrm{~m} / \mathrm{s}, 2.410^{-10} \mathrm{~m} / \mathrm{s}$ and $2.610^{-10} \mathrm{~m} / \mathrm{s}$, respectively. The good agreement between the permeability results achieved experimentally using the modified triaxial cell and the values found in the literature demonstrates the validity of the experimental procedure discussed here.

\subsection{Test procedure and parametric study}

The internal erosion tests are conducted to examine three parameters (kaolin content, hydraulic gradient and filter opening size). The tests are performed on samples with $10 \%$ and $30 \%$ kaolin contents, respectively. The chosen $8 \%$ water content corresponds to a compacted dry unit weight of $17 \mathrm{kN} / \mathrm{m}^{3}$. The confinement pressure is kept steady at $200 \mathrm{kPa}$, which is equivalent to the earth pressure found 
$12 \mathrm{~m}$ deep. The hydraulic gradient is constant during each test, from $2 \mathrm{~m} / \mathrm{m}$ to $27 \mathrm{~m} / \mathrm{m}$ for samples with a $10 \%$ kaolin content and from $32 \mathrm{~m} / \mathrm{m}$ to $168 \mathrm{~m} / \mathrm{m}$ for samples with a $30 \%$ kaolin content (Table 1). A $4 \mathrm{~mm}$ pore opening grid is used to survey the migration of all the particles (sand and clay minerals). A woven filter with a $0.08 \mathrm{~mm}$ pore opening is used to examine the erosion of clay particles only.

Table 1. Main characteristics of the tests

\begin{tabular}{|c|c|c|c|c|}
\hline Tests & $\begin{array}{c}\text { Sample kaolin } \\
\text { content (\%) }\end{array}$ & $\begin{array}{c}\text { Sample initial } \\
\text { porosity (\%) }\end{array}$ & $\begin{array}{c}\text { Filter opening } \\
\text { size (mm) }\end{array}$ & $\begin{array}{c}\text { Hydraulic } \\
\text { gradient i (m/m) }\end{array}$ \\
\hline 9 & 10 & 33 & 0.08 & 4 \\
\hline 2 & 10 & 33 & 0.08 & 27 \\
\hline 3 & 10 & 33 & 4 & 2 \\
\hline 4 & 10 & 33 & 4 & 4 \\
\hline 5 & 10 & 33 & 4 & 12 \\
\hline 6 & 10 & 33 & 4 & 22 \\
\hline 7 & 10 & 33 & 4 & 32 \\
\hline 8 & 10 & 33 & 4 & 110 \\
\hline 9 & 30 & 30 & 0.08 & 44 \\
\hline 10 & 30 & 30 & 0.08 & 48 \\
\hline 11 & 30 & 30 & 4 & 92 \\
\hline 12 & 30 & 30 & 4 & 168 \\
\hline 13 & 30 & 30 & 4 & 4 \\
\hline 14 & 30 & 30 & & 4 \\
\hline
\end{tabular}

The continuous measurement of the solid concentration of the effluent allows for the calculation of the erosion rate, $\mathrm{q}_{\mathrm{s}}(\mathrm{t})$, defined as the eroded mass per second and also called the solid flow rate:

$$
\mathrm{q}_{\mathrm{s}}(\mathrm{t})=\mathrm{C}(\mathrm{t}) \mathrm{q}_{\mathrm{w}}(\mathrm{t})
$$

with $\mathrm{C}(\mathrm{t})$, the concentration (in $\mathrm{mg} / \mathrm{cm}^{3}$ ) measured by the optical sensor and $\mathrm{q}_{\mathrm{w}}(\mathrm{t})$, the fluid flow rate (in $\mathrm{cm}^{3} / \mathrm{s}$ ) measured by the injection pressure volume controller. 


\section{Results}

\section{1. $10 \%$ kaolin samples}

With a $0.08 \mathrm{~mm}$ filter opening size and a $4 \mathrm{~m} / \mathrm{m}$ applied hydraulic gradient (test 1), no significant internal erosion is observed. With a $27 \mathrm{~m} / \mathrm{m}$ hydraulic gradient (test 2), on the other hand, the migration of clay particles begins (Figure 5).

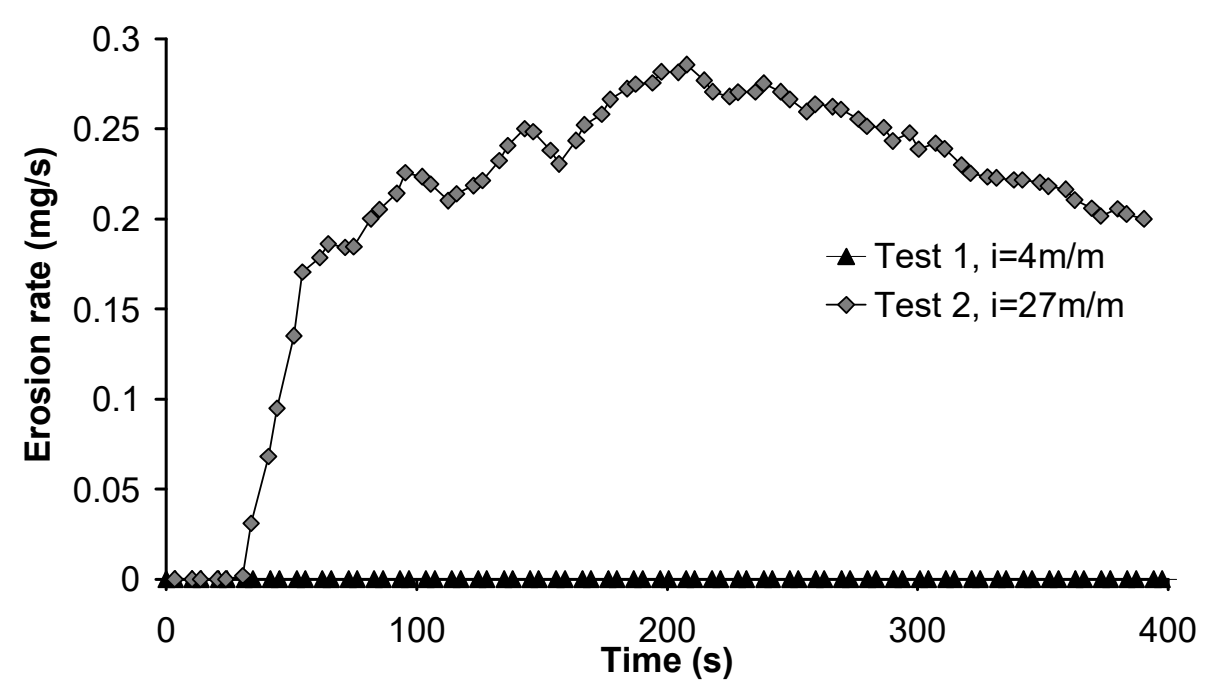

Figure 5. Erosion rate measured on $10 \%$ kaolin samples using a $0.08 \mathrm{~mm}$ filter opening and for $i=4 \mathrm{~m} / \mathrm{m}$ and $i=27 \mathrm{~m} / \mathrm{m}$, respectively

For a $4 \mathrm{~mm}$ filter opening, a $2 \mathrm{~m} / \mathrm{m}$ hydraulic gradient does not initiate any measurable migration of particles (test 3 ). When $\mathrm{i}=4 \mathrm{~m} / \mathrm{m}$ (test 4 ), on the other hand, a continuous low migration of clay particles $(<0.1 \mathrm{mg} / \mathrm{s})$ is observed (Figure 6). With a $4 \mathrm{~mm}$ filter opening, the critical hydraulic gradient is then approximately $4 \mathrm{~m} / \mathrm{m}$. When $\mathrm{i}=8 \mathrm{~m} / \mathrm{m}$, the clay migration quickens until reaching $0.9 \mathrm{mg} / \mathrm{s}$. However, in this case, two successive phases are observed: first, a sharp increase of the erosion rate up to $0.9 \mathrm{mg} / \mathrm{s}$ at 70 seconds and then, a progressive decrease of the rate down to nearly zero between 70 s and 400s (Figure 6). The shape of the erosion rate vs. time curve suggests that the departure of some clay particles even at a low rate $(0.9 \mathrm{mg} / \mathrm{s})$ generates some structural changes within the tested samples.

Thus, in order to examine the sample hydraulic performances, we measure the evolution of the sample hydraulic permeability during the erosion tests with $\mathrm{i}=2 \mathrm{~m} / \mathrm{m}$ and $\mathrm{i}=8 \mathrm{~m} / \mathrm{m}$. The Reynolds number, given by Equation [3], being lower than 4 ( $R e=0.001$ in this case), the permeability, k, can be calculated using Darcy's law:

$$
\operatorname{Re}=\mathrm{v} \frac{\mathrm{d}_{50}}{\mathrm{v}}
$$


where $\mathrm{v}$ is the flow velocity $(\mathrm{m} / \mathrm{s}) ; \mathrm{d}_{50}$, the grain mean diameter $(\mathrm{m})$ and $\mathrm{v}$, the kinematic viscosity $\left(\mathrm{m}^{2} / \mathrm{s}\right)$.

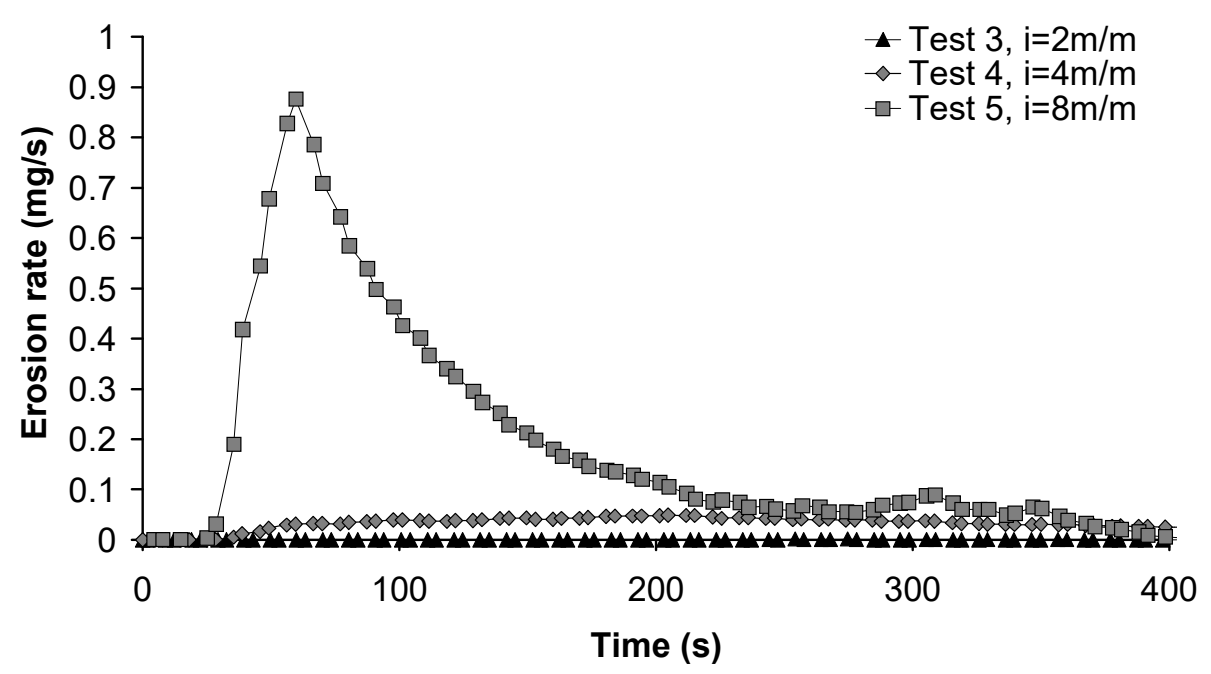

Figure 6. Erosion rate with a $4 \mathrm{~mm}$ filter opening and 10\% kaolin samples (low gradient)

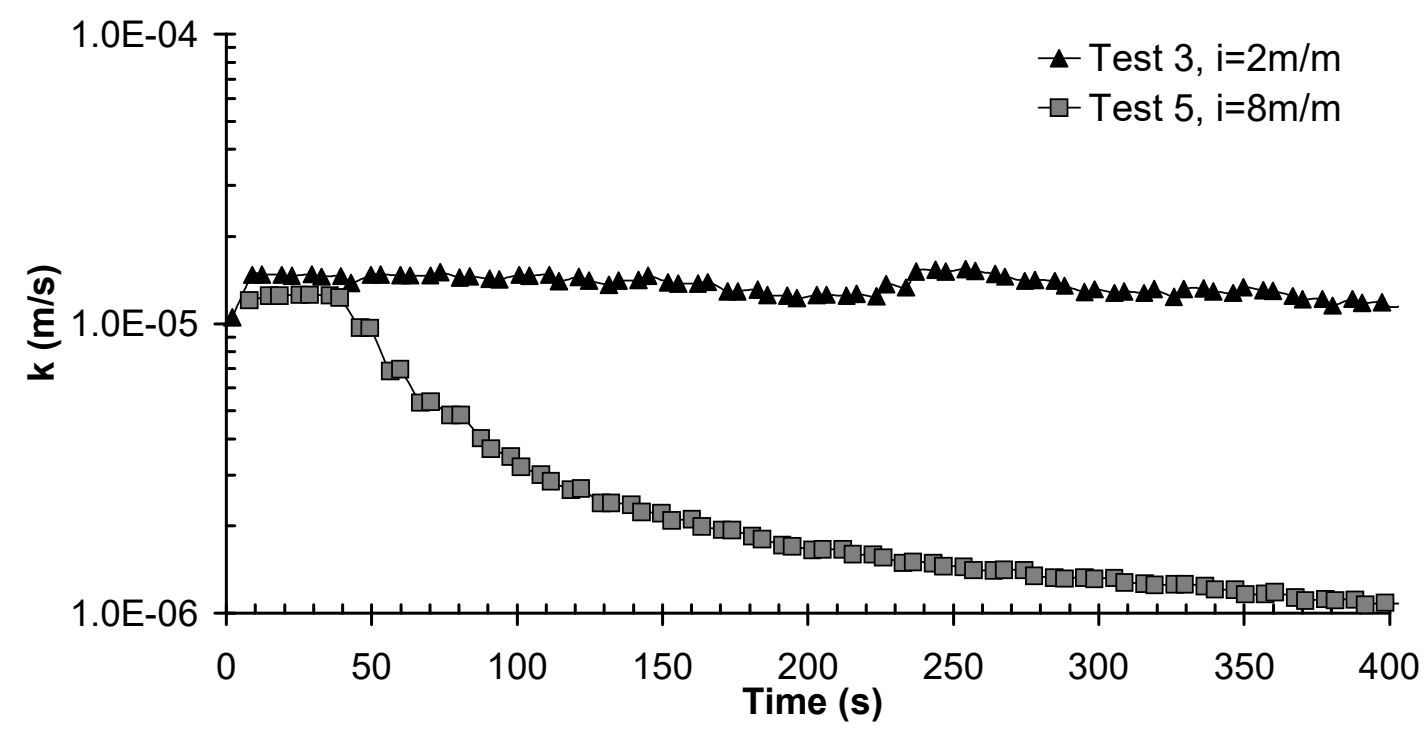

Figure 7. Permeability versus time measured on $10 \%$ kaolin samples using a $4 \mathrm{~mm}$ filter opening with $i=2 \mathrm{~m} / \mathrm{m}$ and $i=8 \mathrm{~m} / \mathrm{m}$

For $\mathrm{i}=2 \mathrm{~m} / \mathrm{m}$, the absence of migration agrees with the constant hydraulic permeability measured. We note that the hydraulic permeability of the $10 \%$ kaolin sample $\left(\mathrm{k}=1.10^{-5} \mathrm{~m} / \mathrm{s}\right)$ is higher than the bentonite samples one $\left(2.10^{-10} \mathrm{~m} / \mathrm{s}\right)$. For $\mathrm{i}=8 \mathrm{~m} / \mathrm{m}$, the decrease of the erosion rate observed between $70 \mathrm{~s}$ and $400 \mathrm{~s}$ coincides with the decrease of $\mathrm{k}$ from the initial $1.10^{-5} \mathrm{~m} / \mathrm{s}$ down to $1.10^{-6} \mathrm{~m} / \mathrm{s}$ (Figure 7). 
With a hydraulic gradient of $27 \mathrm{~m} / \mathrm{m}$, the migration of particles is particularly intense and gives erosion rate values beyond the upper limit of the optical sensor $(6 \mathrm{mg} / \mathrm{s})$. The quantity of particles washed out from the sample is then calculated by continuously weighing the effluents (Figure 8).

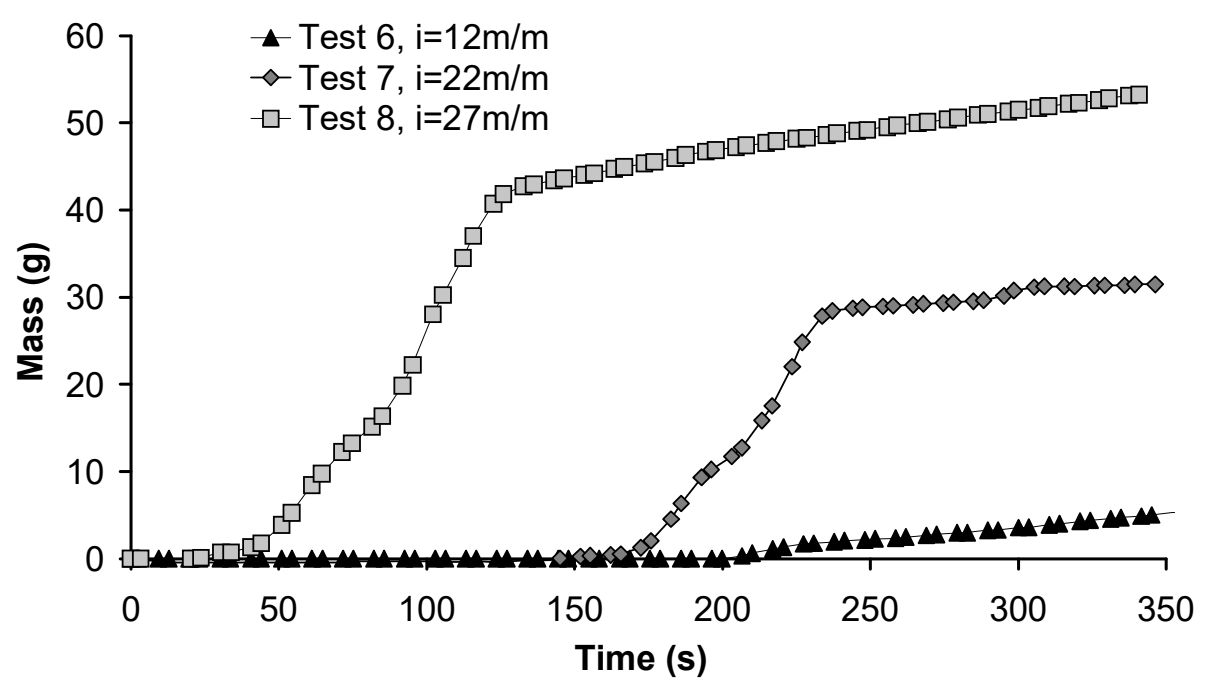

Figure 8. Cumulative mass of effluents measured during the 12, 22 and $27 \mathrm{~m} / \mathrm{m}$ hydraulic gradient experiments on the $10 \%$ kaolin samples with a $4 \mathrm{~mm}$ filter opening

The mass versus time curves for 12,22 and $27 \mathrm{~m} / \mathrm{m}$ hydraulic gradients present similar shapes, which reveal a mechanism of internal erosion in three successive stages:

- the first stage is characterized by an eroded mass nearly null;

- the second stage shows a sharp increase in the cumulated eroded mass;

- and in the third stage, the increase in the cumulated eroded mass is much smaller.

The discontinuity between each successive stage is indicated by break points. The break points between first and second stages are plotted on the graph time axis according to i: $40 \mathrm{~s}, 170 \mathrm{~s}$ and $220 \mathrm{~s}$ for $27 \mathrm{~m} / \mathrm{m}, 22 \mathrm{~m} / \mathrm{m}$ and $12 \mathrm{~m} / \mathrm{m}$, respectively. They indicate a decrease in the erosion initial time as a function of the hydraulic gradient rise. The break points between second and third stages are easily identifiable on the 22 and $27 \mathrm{~m} / \mathrm{m}$ curves. The increase in the hydraulic gradient accelerates the phenomenon and increases the amount of eroded clay particles (Figure 8). The third stage is characterized by similar linear cumulative eroded masses within the range $0.02-0.05 \mathrm{~g} / \mathrm{s}$. The great quantity of eroded material measured during the $27 \mathrm{~m} / \mathrm{m}$ hydraulic gradient experiment signifies that the sample progressively decreases in volume during the test. The shrinkage first appears at the bottom of the sample (Figure 9b) and progresses upwards until the sample fully collapses (Figure 9c). 


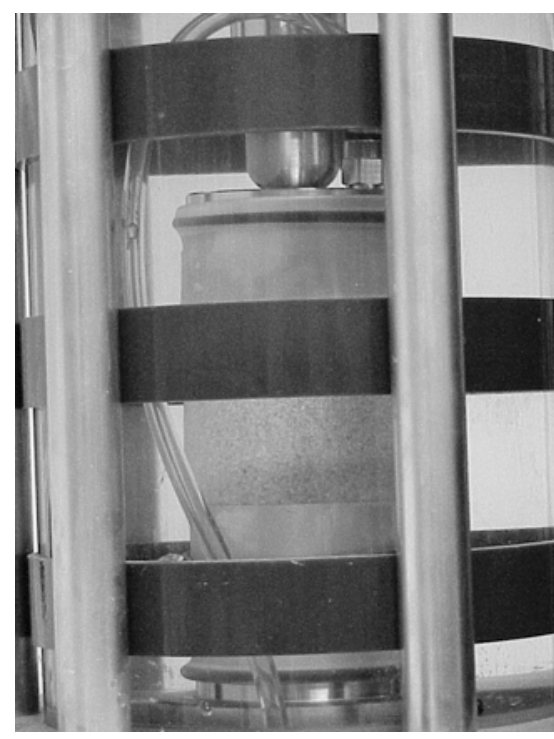

a) Before test

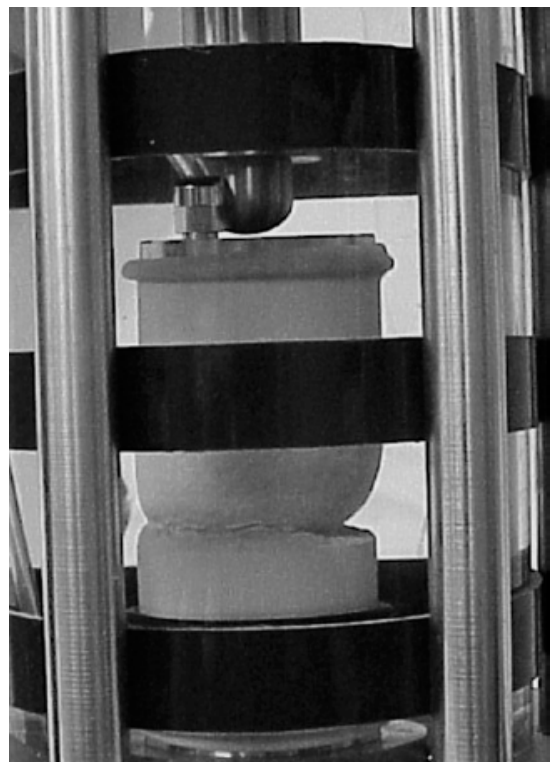

b) During test

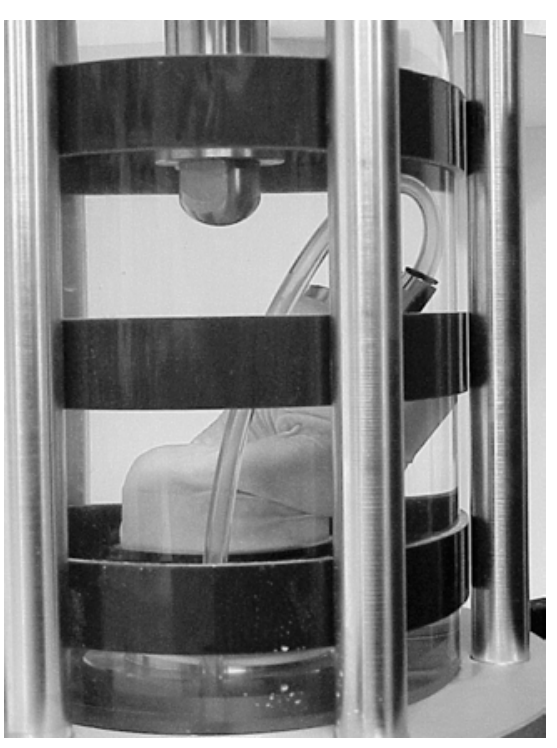

c) After test

Figure 9. Pictures of the sample in the triaxial cell (test 8), a) sample initial state, b)shrinkage of the sample bottom during the erosion test $(i=27 \mathrm{~m} / \mathrm{m}), \mathrm{c})$ sample final collapse

\section{2. $30 \%$ kaolin samples}

The tests are performed on the 30\% kaolin samples using some 0.08 and $4 \mathrm{~mm}$ filter openings, respectively. The quantity of clay particles eroded using the $0.08 \mathrm{~mm}$ filter opening is too small to be measured. Consequently, no internal erosion is observed in spite of high hydraulic gradients up to $110 \mathrm{~m} / \mathrm{m}$.

With the $4 \mathrm{~mm}$ filter opening, on the other hand, variable and increasing erosion rates are measured according to the increasing hydraulic gradients $(44,48,92 \mathrm{~m} / \mathrm{m}$ (Figure 10) and $168 \mathrm{~m} / \mathrm{m}$ (Figure 11)):

- no significant measurements (erosion rate $=0 \mathrm{mg} / \mathrm{s}$ ) when $\mathrm{i}=44 \mathrm{~m} / \mathrm{m}$,

- maximum erosion rate of $0.002 \mathrm{mg} / \mathrm{s}$ when $\mathrm{i}=48 \mathrm{~m} / \mathrm{m}$,

- maximum erosion rate of $0.008 \mathrm{mg} / \mathrm{s}$ when $\mathrm{i}=92 \mathrm{~m} / \mathrm{m}$,

- maximum erosion rate of $4.6 \mathrm{mg} / \mathrm{s}$ when $\mathrm{i}=168 \mathrm{~m} / \mathrm{m}$.

The 48 and $92 \mathrm{~m} / \mathrm{m}$ hydraulic gradient experiments display the same three stages already observed with the $10 \%$ kaolin samples (first, nearly null eroded mass, then, a sharp increase in the eroded mass and third, the eroded mass increases slightly. 


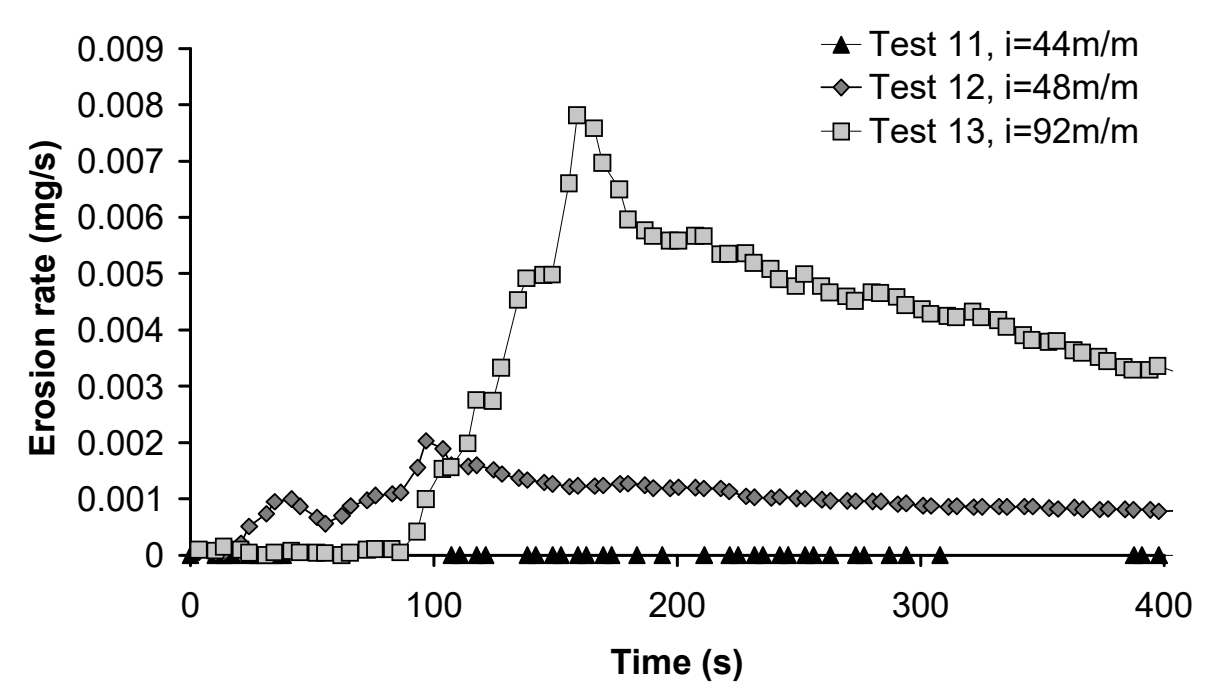

Figure 10. Erosion rates with a $4 \mathrm{~mm}$ filter opening and $30 \%$ kaolin samples for $i=44,48$ and $92 \mathrm{~m} / \mathrm{m}$, respectively

The test conducted with a $168 \mathrm{~m} / \mathrm{m}$ hydraulic gradient presents some very high erosion rates (up to $4.7 \mathrm{mg} / \mathrm{s}$ ) while, contrary to the other tests, we note the absence of the first stage (eroded mass nearly null).

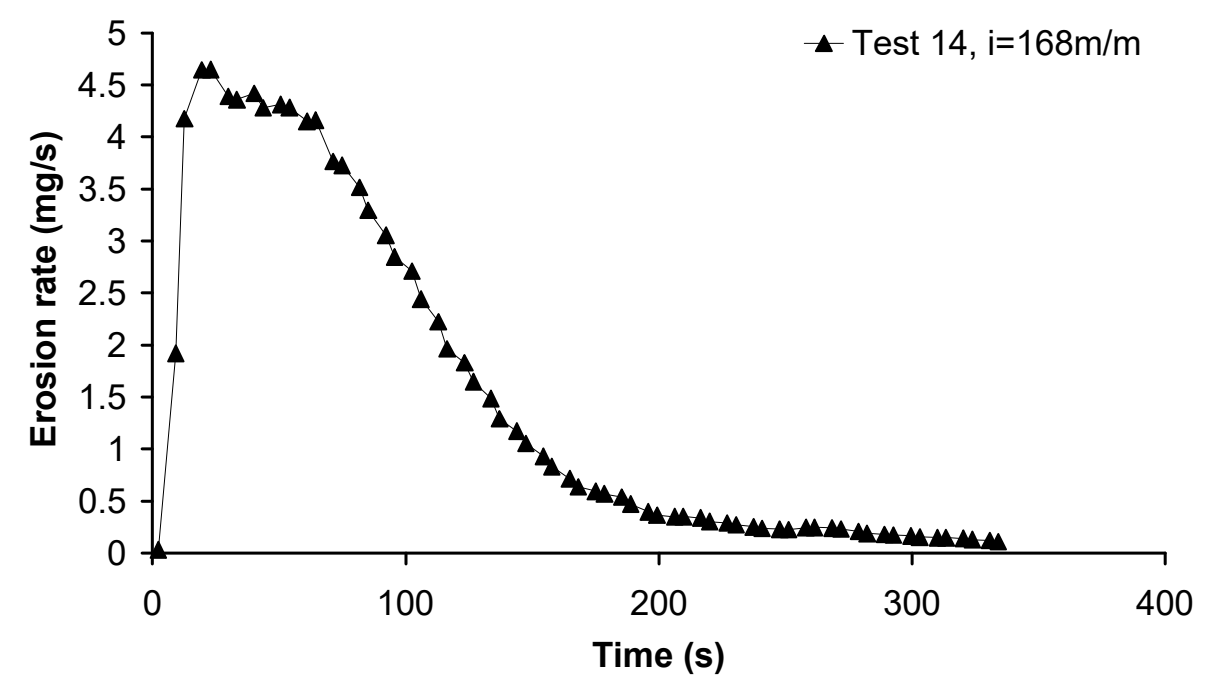

Figure 11. Erosion rate with $4 \mathrm{~mm}$ filter opening and $30 \%$ kaolin samples (very high hydraulic gradient)

\section{Discussion}

The test results present some extremely differing erosion rate values ranging from $\mathrm{q}_{\mathrm{s}}<1 \mu \mathrm{g} / \mathrm{s}$, for some tests, to $\mathrm{q}_{\mathrm{s}}>1 \mathrm{mg} / \mathrm{s}$, for some others. For most of the other tests, however, some moderate erosion rate values have been obtained. The clay content, here, seems to affect soil erodibility significantly. The results show that for a $10 \%$ kaolin sample, the erosion rate is about seven times higher than for a $30 \%$ kaolin sample. As the kaolin content increases, the initial permeability decreases 
$\left(2.510^{-5} \mathrm{~m} / \mathrm{s}\right.$ for a $10 \%$ of kaolin content and $1.510^{-7} \mathrm{~m} / \mathrm{s}$ for a $\left.30 \%\right)$, causing the global flow within the samples to be falling. The decrease in the particulate water velocity $\mathrm{v}_{\mathrm{p}}$ can be estimated as:

$$
\mathrm{v}_{\mathrm{p}}=\frac{\mathrm{v}}{\mathrm{n}}
$$

where $\mathrm{v}$ is the flow velocity within the sample $(\mathrm{m} / \mathrm{s})$ and $\mathrm{n}$, the porosity.

Darcy's law gives:

$$
\mathrm{v}_{\mathrm{p}}=\frac{\mathrm{k} . \mathrm{i}}{\mathrm{n}}
$$

For a given hydraulic gradient and two kaolin content values (10 and 30\%):

$$
\mathrm{i}=\mathrm{cst}=\frac{\mathrm{v}_{\mathrm{p} 30 \%} \mathrm{n}_{30 \%}}{\mathrm{k}_{30 \%}}=\frac{\mathrm{v}_{\mathrm{p} 10 \%} \mathrm{n}_{10 \%}}{\mathrm{k}_{10 \%}}
$$

Therefore,

$$
\mathrm{v}_{\mathrm{p} 30 \%}=0.0066 . \mathrm{v}_{\mathrm{p} 10 \%}
$$

with: $\mathrm{n}_{30 \%}=30 \%$ and $\mathrm{n}_{10 \%}=33 \%, \mathrm{k}_{30 \%}=1 \cdot 5 \cdot 10^{-7} \mathrm{~m} / \mathrm{s}$ and $\mathrm{k}_{10 \%}=2 \cdot 5 \cdot 10^{-5} \mathrm{~m} / \mathrm{s}$.

This solution shows that the particulate velocity within sand/clay samples with a $30 \%$ kaolin content is 150 times slower than with $10 \%$ kaolin samples. When the velocity decreases, the strain generated by the flow within the samples also decreases and contributes to increase the internal erosion resistance.

For a $4 \mathrm{~mm}$ filter opening, the critical hydraulic gradient is $4 \mathrm{~m} / \mathrm{m}$ but with a $0.08 \mathrm{~mm}$ filter opening, it can be six or seven times higher. Consequently, the filter opening size is an important parameter to qualify the erosion rate in the same way as the hydraulic gradient.

For a hydraulic gradient slightly higher than the critical gradient (test 5), the erosion of a small amount of clay is accompanied by a decrease of ten times the permeability of the same material, within which not erosion is initiated (test 3 ). No significant volume change being observed, the permeability decrease may be accounted for by some local porosity alterations due to the internal rearrangement of the clay particles. This phenomenon is known as suffusion.

For a high hydraulic gradient, the extensive particle migration generated causes some substantial volume changes at the bottom of the sample, which finally collapses. This phenomenon is known as piping. 
These elements confirm Barakat (1991)'s results, who represents sand/clay samples as a double structure set: a primary structure, sand, and a secondary structure, clay. Subjected to a low hydraulic gradient, the secondary structure, only, is eroded without modifying the mechanical resistance. With a high hydraulic gradient, on the other hand, both the first and the secondary structures are altered, which causes the collapse.

With the intention of considering the three parameters (hydraulic gradient, permeability and porosity), we calculate the hydraulic shear stress using Equation [1] for all the tests. The maximum solid content $\left(\mathrm{C}_{\max }\right)$ is the maximum value achieved during the tests.

From the results obtained thanks to the samples tested with hydraulic gradients between 2 and $168 \mathrm{~m} / \mathrm{m}$, it is possible to represent the maximum concentration versus the hydraulic shear stress. This representation is a linear function (Figure 12). The intersection of the linear curve with the hydraulic shear stress axis indicates the critical hydraulic shear stress $\left(\tau_{\text {cr }}\right.$ ) (equal to $0.03 \mathrm{~Pa}$ and $0.15 \mathrm{~Pa}$ for $10 \%$ and $30 \%$ kaolin contents and a $4 \mathrm{~mm}$ pore filter, respectively).

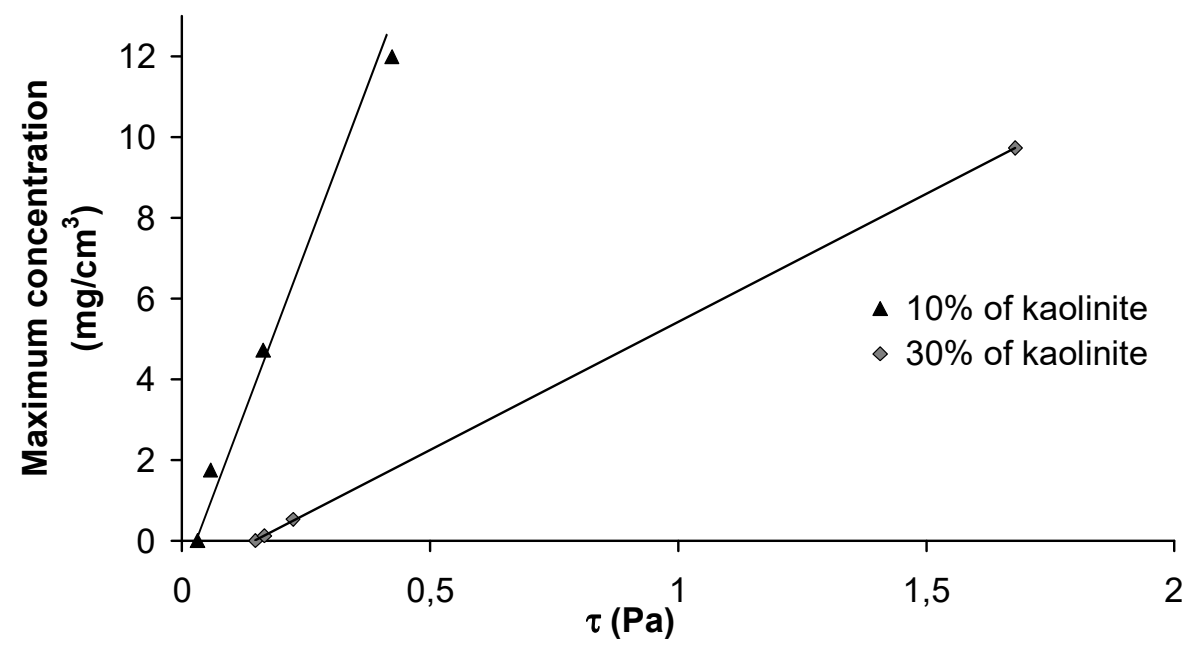

Figure 12. Maximum concentration versus hydraulic shear stress with a $4 \mathrm{~mm}$ filter opening

The experimental data are satisfactorily fitted (4 points, correlation coefficient $\left.\mathrm{R}^{2}=0.99\right)$ by the linear function. However, some additional investigations are required to confirm the relationship between the concentration and the hydraulic shear stress.

\section{Conclusion}

The mechanisms responsible for the internal erosion are very evolutionary and depend on many parameters. In the face of such complexity, the internal erosion 
initiation and development criteria found in the literature are closely dependent on the studied structures and, therefore diverse.

The experimental device described here can be used to saturate and consolidate reconstituted sand/clay samples. The triaxial cells used for the parametric study have been modified to let the flow comes through up to the core of the sample.

The comparison of the first results achieved here with those obtained by Kenney et al. (1992) on sand/bentonite samples demonstrates the good repeatability of the tests and validates the experimental procedure. Thanks to this device, the mechanisms that initiate internal erosion within sand/kaolin samples have been examined. All the tests are carried out on sand/clay samples with a $10 \%$ or $30 \%$ kaolin content, respectively, and with hydraulic gradients ranging between 2 and $168 \mathrm{~m} / \mathrm{m}$.

The value of the critical hydraulic gradient depends on the kaolin content. A hydraulic gradient higher than the critical value produces, first, a migration of the clay particles through a phenomenon of suffusion. If the hydraulic gradient keeps on increasing, the sample structure is modified because the sand grains are transported by the phenomenon of piping. Finally, the skeleton becomes unstable and the sample collapses.

A high sand/clay ratio contributes to decrease the flow velocity within the sample while increasing the internal erosion resistance. The use of geotextile filters also reduces particle transportation.

For both tested clay percentages, the maximum effluent concentration is a linear function of the hydraulic shear stress.

To improve our understanding of these phenomena, we need additional information, which could be achieved by carrying out complementary tests to examine other sand/clay ratios and filter opening sizes. The experimental device potential can also be used to study the effects of the confining pressure on internal erosion kinetics. A preliminary calibration of the optical sensor to suit a larger range of clay minerals will also make it possible to study the influence of clay sensibility.

\section{Bibliography}

AFNOR (NF P 94-074), Essais à l'appareil triaxial de révolution, Association Française de Normalisation, 1994.

Arulanandan K., Perry E. B., "Erosion in relation to filter design criteria in earth dams", Journal of Geotechnical Engineering, Vol. 109, No. 5, 1983, p. 682-696.

Barakat B., Instabilité aux écoulements des milieux granulaires, aspects morphologiques et probabilistes, Ph.D report Ecole Centrale de Paris, 1991.

Bendahmane F., Influence de l'écoulement sur la résistance des sols: étude expérimentale préliminaire, Master report, Université de Nantes, 2002. 
Foster M., Fell R., "Spannagle M., The statistics of embankment dam failures and accidents", Canadian Geotechnical Journal, Vol. 37, 2000, p. 1000-1024.

Kenney T. C., Lau D., "Internal stability of granular filters", Canadian Geotechnical Journal, Vol. 22, 1985, p. 215-225.

Kenney T. C., Van Veen W. A., "Swallow M A., Sungaila M A., hydraulic conductivity of compacted-sand mixtures", Canadian Geotechnical Journal, Vol. 29, 1992, p. 364-374.

Khilar K. C., Fogler H. S., Gray D. H., "Model for piping-plugging in earthen structures", Journal of Geotechnical Engineering, Vol. 111, No. 7, 1985, p. 833-846.

Monnet A., Boulance, «Erosion interne, renard. Les instabilités sous écoulement », Revue Française de Géotechnique, Vol. 82, 1998, p. 3-10.

Reddi L. N., Lee I., Bonala M. V. S., "Comparison of internal and surface erosion using flow pump test on a sand-kaolin mixture", Geotechnical Testing Journal, Vol. 23, No. 1, 2000, p. 116-122.

Skempton A. W., Brogan J. M., "Experiments on piping in sandy gravels", Géotechnique, Vol. 44, No. 3, 1994, p. 440-460. 